\title{
Oligosaccharide production and proteolysis during lactose hydrolysis using crude cellular extracts from lactic acid bacteria
}

\author{
Todor VASILJEVIC, Paul JELEN* \\ Department of Agricultural, Food and Nutritional Science, 206 Agricultural/Forestry Center, \\ University of Alberta, Edmonton, Alberta, Canada
}

(Received 30 December 2002; accepted 12 June 2003)

\begin{abstract}
The extent of the lactose hydrolysis and oligosaccharide formation through transgalactosyl reactions by crude cellular extracts (CCE) containing intracellular $\beta$-galactosidase from disrupted Lactobacillus delbrueckii subsp. bulgaricus 11842, Lactobacillus delbrueckii subsp. lactis DMF 3078 or Streptococcus thermophilus 143 was investigated in lactose-containing buffered solutions or skim milk. Lactose hydrolysis was performed with lactose concentration ranging from 5 to $30 \%(\mathrm{w} / \mathrm{w})$ at $30,40,50$ or $60^{\circ} \mathrm{C}$ and terminated after $120 \mathrm{~min}$. The proteolytic activities of the CCEs in skim milk systems were also assessed. All CCEs produced di-, tri- and tetrasaccharides in addition to monosaccharides as major products of the lactose hydrolysis in buffered lactose solutions. However, only $\mathrm{Lb}$. lactis produced tetrasaccharides at detectable levels in skim milk preparations. The amount and the rate of oligosaccharide formation were significantly $(P<0.05)$ affected by the origin of the enzyme, lactose concentration and temperature. The maximum oligosaccharide production by all CCEs was reached at $50{ }^{\circ} \mathrm{C}$ in $30 \%(\mathrm{w} / \mathrm{w})$ lactose solution. St. thermophilus CCE produced significantly higher $(P<0.05)$ amounts of oligosaccharides than the other two CCE preparations at all lactose concentrations studied. However, Lb. bulgaricus CCE showed better lactose-hydrolyzing ability and higher proteolytic activity than the other two CCEs. The lactose hydrolysis generally proceeded faster at $50-60{ }^{\circ} \mathrm{C}$ than at $30-40{ }^{\circ} \mathrm{C}$ as opposed to the proteolytic maxima reached at $40^{\circ} \mathrm{C}$.
\end{abstract}

Crude cellular extract / $\beta$-galactosidase / thermophilic dairy culture / lactose hydrolysis / transferase reaction / proteolytic activity

Résumé - Production d'oligosaccharides et protéolyse lors de l'hydrolyse de lactose par extraits cellulaires bruts de bactéries lactiques. Le degré d'hydrolyse du lactose et la formation d'oligosaccharides par réaction de transgalactosylation sous l'action d'extraits cellulaires bruts (ECB) contenant de la $\beta$-galactosidase obtenue par rupture de Lactobacillus delbruekii subsp. bulgaricus 11842, Lactobacillus delbruekii subsp. lactis DMF 3078 et Steptococcus thermophilus 143 ont été étudiés sur des solutions tamponnées de lactose ou sur le lait écrémé. L’hydrolyse du lactose a été effectuée sur des concentrations de 5 à $30 \%$ (masse) à des températures de 30, 40, 50 et $60{ }^{\circ} \mathrm{C}$ pour une durée totale de $120 \mathrm{~min}$. L'activité protéolytique des ECBs sur les systèmes à base de lait écrémé a également été évaluée. Tous les ECBs ont produit des di-, tri- et tetrasaccharides en plus des monosaccharides comme composants majeurs de l'hydrolyse du lactose contenu dans les solutions tamponnées. Toutefois, seul Lb. lactis a produit des tetrasaccharides à un niveau

\footnotetext{
*Corresponding author: paul.jelen@ualberta.ca
} 
significatif avec le lait écrémé. La quantité et la vitesse de formation d'oligosaccharides ont été affectées de manière significative $(P<0.05)$ par la provenance de l'enzyme, la concentration en lactose et la température. La production maximale d'oligosaccharides, pour tous les ECBs a été obtenue à $50{ }^{\circ} \mathrm{C}$ et une concentration en lactose de $30 \%$ (masse). Les ECBs provenant de St. thermophilus ont produit de façon significative $(P<0.05)$ plus d'oligosaccharides que les deux autres préparations, ceci pour toute concentration en lactose. Toutefois, Lb. bulgaricus ECB a montré une plus grande capacité d'hydrolyse et une activité protéolytique supérieure aux deux autres ECBs. L'hydrolyse du lactose s'effectue généralement plus rapidement à 50-60 ${ }^{\circ} \mathrm{C}$ qu'à 30 $40{ }^{\circ} \mathrm{C}$ alors que l'activité protéolytique atteint son maximum à $40^{\circ} \mathrm{C}$.

Extrait cellulaire brut / $\beta$-galactosidase / bactérie thermophile / hydrolyse du lactose / reaction de transférase / activité protéolytique

\section{INTRODUCTION}

The lactose-hydrolyzing ability of crude cellular extracts (CCE) containing $\beta$-galactosidase (EC 3.2.1.23, $\beta$-gal) from mechanically disrupted Lactobacillus delbrueckii ssp. bulgaricus 11842 (Lb11842) has been explored extensively [14-16, 25, 33]. However, little attention has been paid to date to the catalytic ability of the CCE regarding the transferase reactions, another important property of bacterial $\beta$-gal. The proteolytic activity of the Lb11842 CCE preparation has been described in a preliminary way [33]. Such activity, if not controlled properly, could interfere with lactose hydrolysis due to $\beta$-gal digestion [7]. Alternatively, for some uses of the CCE, the proteolytic reactions may be desirable and thus these should be well characterized.

The transferase reactions include the internal rearrangement of the lactose molecule with the formation of different disaccharides, as well as transgalactosyl reactions, resulting in creation of tri- and higher oligosaccharides [21]. The transferase products are hydrolyzed very slowly by the human $\beta$-galactosidase in the small intestine, which may result in gastrointestinal discomfort and lactose intolerance-like symptoms [18]. More recently, several studies showed the positive effect of oligosaccharide addition on the microbial microflora, influencing the increase in fecal bifidobacteria and modifying the colonic fermentation metabolism in the gut of healthy humans [3], or reducing the colon cancer risk in carcinogentreated rats [5].
The transferase reactions have been described for highly purified $\beta$-gal preparations obtained from a number of microbial sources $[6,11,20,27,29,31]$. Using $\beta$-gal in the batch mode was suggested for maximization of oligosaccharide production [22]. No attempt has been made so far to study the oligosaccharide-producing capability of the $\beta$-gal-containing CCE, although the work of Kreft et al. [16] offered some indications that oligosaccharides were indeed produced during lactose hydrolysis by Lb11842 CCE in buffered lactose solutions. The oligosaccharides could also be produced by glycosyltransferases, involved in the biosynthesis of exopolysaccharides by numerous LAB strains [2], that would be found in the CCE after cell disruption.

Thermophilic LAB, especially mixed yogurt cultures, possess appreciable proteolytic activity [26]. The cell-enveloped proteases and different intracellular peptidases result in an efficient breakdown of casein, major milk protein, into different amino acids and peptides required for cell growth [17, 28]. Several studies reported $\mathrm{pH}$ and temperature dependence of the protease activity of several thermophilic LAB species $[1,4]$. The high proteolytic activity of a $\beta$-gal preparation could be undesirable during lactose hydrolysis in milk since it may result in bitterness [19] as well as the digestion of the $\beta$-gal enzyme. The proteolytic activity in CCE preparations would be expected, since CCE are mixtures of liberated intracellular enzymes as well as cell debris. The minimization or maximization 
of the proteolytic activity by controlling the environmental conditions (temperature, time and substrate concentration) during lactose hydrolysis may therefore be required, depending on a targeted use of the $\beta$-gal-containing CCE.

The main objectives of our study were to (1) compare the lactose-hydrolyzing ability of the $\beta$-gal-containing CCEs prepared using three alternative thermophilic LAB sources in buffered lactose and skim milk systems at different temperatures; (2) characterize the transferase reactions during lactose hydrolysis in buffered lactose and skim milk systems at different temperatures of the three $\beta$-gal-containing CCE preparations; and (3) describe the proteolytic activity of the three CCE preparations during lactose hydrolysis in skim milk. The well-characterized Lactobacillus delbrueckii ssp. bulgaricus 11842 was included in these studies for comparison with Lactobacillus delbrueckii subsp. lactis DMF 3078 and Streptococcus thermophilus 143, two other organisms with known high $\beta$-gal-producing capability.

\section{MATERIALS AND METHODS}

\subsection{Culture cultivation and cell collection}

Lactobacillus delbrueckii ssp. bulgaricus ATCC 11842 (Lb11842) was obtained from the University of Alberta, Department of Agricultural, Food and Nutritional Science. Lactobacillus delbrueckii ssp. lactis DMF 3078 (Lb3078) and Streptococcus thermophilus 143 (St143) were provided by the Department of Milk and Fat Technology, Institute of Chemical Technology, VSCHT, Prague, Czech Republic. The cultures were cultivated in pasteurized commercial skim milk (Lucerne milk processing plant, Edmonton, AB, Canada) as described by Geciova et al. [8]. Fermentations were conducted for $10 \mathrm{~h}$ in a $50 \mathrm{~L}$ fermentor at $43^{\circ} \mathrm{C}$ and $\mathrm{pH}$ was maintained by $10 \mathrm{~mol} \cdot \mathrm{L}^{-1} \mathrm{KOH}$ at 5.6 for Lactobacillus sp. and 5.8 for Streptococcus. After the fermentations, the cell collection and handling were performed as reported previously [34]. Before the production of the CCE, the cell paste samples from each fermentation were randomly selected for the determination of the total solids and the $\beta$-gal activity by oven drying and the ONPG (o-nitrophenyl$\beta$-D-galactopyranoside) method, respectively [32]. A unit of enzyme activity (U) was defined as the amount of enzyme required to hydrolyze $1 \mu \mathrm{mol}$ of ONPG $\mathrm{min}^{-1}$ at $37^{\circ} \mathrm{C}$ under conditions described previously [33].

\subsection{Preparation of crude cellular extracts and reaction mixtures}

The crude $\beta$-galactosidase preparations were obtained in a similar way to that described before [34]. Prior to cell disruption for the liberation of the intracellular $\beta$ gal, the frozen cell paste (14-16\% dry matter) was thawed at $37^{\circ} \mathrm{C}$ in a water bath and reconstituted either in $\mathrm{pH} 6.8$ skim milk salt buffer-SMSB [24] or a $10 \%(\mathrm{w} / \mathrm{v})$ solution of low heat skim milk powder (Dairyworld foods, Vancouver, BC, Canada) resulting in preparations containing approximately $10 \%$ cell paste total solids in both cases. The liberation of intracellular $\beta$-gal was achieved using a one-pass treatment with two ceramic disrupting chambers of a microfluidizer (Model M-110EH, Microfluidics, Newton, MA, USA) as described by Geciova et al. [8]. These treated preparations, denoted as crude cellular extracts (CCE) in further text, were used without further purification.

\subsection{Lactose hydrolysis and quantification of reaction products}

The reaction systems for lactose hydrolysis were prepared either by dissolving appropriate amounts of lactose monohydrate (Fisher Scientific Limited, Nepean, ON, Canada) in SMSB to give 5, 12.5, 20 or $30 \%(\mathrm{w} / \mathrm{w})$ final lactose concentration, or by reconstituting the low temperature 
skim milk powder (Dairyworld foods) in deionized water to prepare solutions giving 10,20 or $30 \%(\mathrm{w} / \mathrm{w})$ final total skim milk solids content upon recombining with the CCE preparations.

The CCE preparations were combined with the lactose or skim milk solutions, giving reaction mixtures containing approximately $10 \mathrm{U} \cdot \mathrm{mL}^{-1} \beta$-gal activity, which corresponded to the final cell paste total solids content ranging between 2 and 3\% $(w / v)$. The reaction mixtures were held at $30,40,50$, or $60^{\circ} \mathrm{C}$ for $120 \mathrm{~min}$. Samples $(1 \mathrm{~mL})$ were taken after 30,60 and $120 \mathrm{~min}$ and the reaction was terminated by alcohol precipitation [33]. The time frame selected was based on the report of Greenberg and Mahoney [10], indicating that maximum oligosaccharide production in milk was achieved within $2 \mathrm{~h}$ of the lactose hydrolysis process. This reaction period would probably minimize the likelihood of the oligosaccharide formation by other glycosyltransferases.

The formation of monosaccharides and oligosaccharides was quantified by high performance liquid chromatography (HPLC) equipped with Shimadzu Ezchrom Chromatography processing system (Shimadzu Precision Instruments, Torrance, CA, USA). The mono- and disaccharides were separated by a Supelcosil $\mathrm{LC}-\mathrm{NH}_{2}-5 \mu \mathrm{m}$ column (Supelco, Bellefonte, PA, USA; 25 cm length and $4.6 \mathrm{~mm}$ diameter) as previously reported [35]. An oligosaccharide column (Jordi Gel, DVB Polyamine column, $250 \mathrm{~mm}$ length and $4.6 \mathrm{~mm}$ diameter, Bellingham, MA, USA) was used to separate oligosaccharides. Elution was accomplished similarly to the determinations by the Supelcosil column, using a gradient of two mobile phase solvents: deionized water and acetonitrile (HPLC grade). The concentration of acetonitrile was decreased linearly over $25 \mathrm{~min}$ from 90 to $60 \%$, increa-sed to $100 \%$ at $26 \mathrm{~min}$, and then decreased to $90 \%$ at the end of the determination. The total run time was $30 \mathrm{~min}$. The total flow rate was constant at $1 \mathrm{~mL} \cdot \mathrm{min}^{-1}$. In all cases, a $25 \mu \mathrm{L}$ sample was injected by a Hewlett Packard Series 1050 autosampler (HP, Mississauga, ON, Canada). The peaks were identified and concentrations determined by using external standard solutions of glucose, galactose, lactose, maltotriose, maltotetraose, maltopentaose and maltohexaose and corresponding calibration curves. The degree of lactose conversion, expressed as a percentage of the initial lactose content of the sample, was calculated as previously reported [33] by dividing the total monosaccharide concentration $\left(\mathrm{mg} \cdot \mathrm{mL}^{-1}\right)$ by the initial lactose concentration $\left(\mathrm{mg} \cdot \mathrm{mL}^{-1}\right)$.

\subsection{Total proteolytic activity}

The proteolytic activities of the CCE preparations during lactose hydrolysis in skim milk reaction systems were assessed by HPLC peptide mapping of the hydrolyzed products. The conditions employed during the HPLC determinations were described previously [33]. The samples $(1 \mathrm{~mL})$ were taken in a similar way to the samples for the determination of the rate of lactose hydrolysis, diluted ten-fold in deionized water and filtered through a $0.22 \mu \mathrm{m}$ Millipore filter. The HPLC determinations were performed using a Sephasil reverse phase peptide column (Amersham Biosciences, Piscataway, NJ, USA) and Shimadzu Ezchrom Chromatography processing system. The change of absorbance was observed by an ultraviolet/visible wavelength detector (Shimadzu SPD-10A) operating at $220 \mathrm{~nm}$ wavelength. Total peak area was obtained by integration of all the peaks observed. The relative proteolytic activity (RPA, \%), expressing the relative increase in the total peptide content, was calculated from the following equation:

$$
\mathrm{RPA}, \%=\frac{\mathrm{TPA}_{\mathrm{t}}-\mathrm{TPA}_{0}}{\mathrm{TPA}_{0}} \times 100
$$

where $\mathrm{TPA}_{\mathrm{t}}$ and $\mathrm{TPA}_{0}$ are total peak areas at time $\mathrm{t}(30,60$ or $120 \mathrm{~min})$ and at the beginning of the hydrolysis, respectively. 


\subsection{Kinetic parameters}

In order to compare the efficiency of lactose hydrolysis by the three selected $\beta$-gal containing CCE preparations in buffered lactose and skim milk systems, the kinetic parameters, $\mathrm{K}_{\mathrm{m}}$ and $\mathrm{k}_{\mathrm{cat}}$, were evaluated from the concentrations of the monosaccharides released during the first $30 \mathrm{~min}$ of the hydrolysis for all lactose concentrations and temperatures examined. The constants were inferred from the Michaelis-Menten equation using the Lineweaver-Burk method $[32,36]$.

\subsection{Statistical analysis}

All experiments were at least replicated and all subsequent analyses were carried out at least in duplicate resulting in $n=4$ or more. Statistical analysis using all available data was performed by the General Linear Model of SAS (SAS Institute, 1992) as a full factorial, split-plot in time design. The model included all main effects (strain, lactose concentration, temperature and time) and corresponding interactions. Covariate analysis, using the enzyme activity or the cell paste total solids as a covariate, was employed if necessary. The statistical significance was preset at $\alpha=0.05$.

\section{RESULTS AND DISCUSSION}

\subsection{Monosaccharide formation}

The lactose-hydrolyzing effectiveness of the CCEs from the three different LAB sources was compared using the determination of rate constants for lactose hydrolysis as $\mathrm{K}_{\mathrm{m}}$ and $\mathrm{k}_{\text {cat }}$ values and by measuring the monosaccharide formation during the course of the lactose hydrolysis. Generally, the enzyme origin, temperature and medium in which the lactose hydrolysis was performed had a significant $(P<0.01)$ effect on both kinetic parameters (Tab. I). The covariate analysis showed no significant effect $(P=0.4478)$ of the initial $\beta$-gal activ- ity in the CCEs on the kinetic parameters. Shah and Jelen [25] and Garman et al. [6] also reported substantial differences in the $\beta$-gal activity in several different LAB species. The $\mathrm{K}_{\mathrm{m}}$ and $\mathrm{k}_{\mathrm{cat}}$ values obtained for the Lb11842 CCE in the present study were broadly similar to those determined by a different methodology for the same CCE preparation during lactose hydrolysis in $10 \%$ skim milk [33]. The temperature change from 30 to $60^{\circ} \mathrm{C}$ resulted in an increase of approximately 2.5 times in $\mathrm{k}_{\text {cat }}$ regardless of the strain and medium examined (Tab. I). The $\mathrm{K}_{\mathrm{m}}$ values were also positively affected by the temperature increase with an apparent difference among the strains and reaction systems. Notably, the maximum $\mathrm{k}_{\text {cat }}$ and $\mathrm{K}_{\mathrm{m}}$ values were obtained at $50{ }^{\circ} \mathrm{C}$ for all tested strains (Tab. I). The initial rate of lactose hydrolysis was generally higher in skim milk than in the buffered lactose solutions. Mozaffar et al. [20] reported opposite findings as they noted a substantial decrease in the initial velocity of the lactose hydrolysis by $\beta$-gal obtained from $E$. coli or $K$. lactis in milk in comparison with that in a buffered lactose solution. The product inhibition [12], disregarded in our calculations, as well as different enzymes and/or the proteolytic activity of the CCE preparations [33] may likely have important ramifications on the rate of the lactose hydrolysis. The temperature dependence of the catalytic constant $\mathrm{k}_{\mathrm{cat}}$ followed the Arrhenius plot, resulting in significant differences $(P<0.05)$ for the three LAB species studied. The energy of activation $\left(\mathrm{E}_{\mathrm{a}}\right)$ also differed significantly $(P<0.05)$ between the CCE preparations examined (Tab. I). The values obtained in the present study were lower than those determined previously [33], using a different methodology.

The considerable difference between the lactose-hydrolyzing capabilities of the three studied CCEs, described by the different rate constants, $\mathrm{K}_{\mathrm{m}}$ and $\mathrm{k}_{\text {cat }}$, significantly $(P<0.01)$ affected the extent of the monosaccharide formation in all examined preparations. Tables II and III show the final concentrations of glucose and galactose 
Table I. The estimation of Michaelis-Menten-type kinetic parameters, $\mathrm{K}_{\mathrm{m}}$ and $\mathrm{k}_{\mathrm{cat}}$, and the energy of activation, $\mathrm{E}_{\mathrm{a}}$, by Arrhenius plot for lactose hydrolysis in lactose and skim milk preparations at different temperatures using $\beta$-gal-containing CCE produced from three different thermophilic dairy cultures.

\begin{tabular}{|c|c|c|c|c|c|c|}
\hline $\mathrm{CCE}^{*} /$ & \multicolumn{3}{|c|}{ Lactose } & \multicolumn{3}{|c|}{ Skim milk } \\
\hline $\begin{array}{c}\text { Temperature } \\
\left({ }^{\circ} \mathrm{C}\right)\end{array}$ & $\frac{\mathrm{K}_{\mathrm{m}}}{\left(\mathrm{mmol} \cdot \mathrm{L}^{-1}\right)}$ & $\begin{array}{c}\mathrm{k}_{\mathrm{cat}} \\
\left(\mu \mathrm{mol} \cdot \mathrm{U}^{-1} \cdot \min ^{-1}\right)\end{array}$ & $\underset{\left(\mathrm{kJ} \cdot \mathrm{mol}^{-1}\right)}{\mathrm{E}_{\mathrm{a}}}$ & $\frac{\mathrm{K}_{\mathrm{m}}}{\left(\mathrm{mmol} \cdot \mathrm{L}^{-1}\right)}$ & $\underset{\left(\mu \mathrm{mol} \cdot \mathrm{U}^{-1} \cdot \min ^{-1}\right)}{\mathrm{k}_{\mathrm{cat}}}$ & $\underset{\left(\mathrm{kJ} \cdot \mathrm{mol}^{-1}\right)}{\mathrm{E}_{\mathrm{a}}}$ \\
\hline
\end{tabular}

Lb11842

$\begin{array}{rrrrrr}30 & 201.2 & 257.5 & & 97.4 & 203.9 \\ 40 & 244.6 & 294.4 & & 198.4 & 293.4 \\ 50 & 320.9 & 654.9 & & 127.5 & 469.5 \\ 60 & 185.3 & 614.0 & 28.68 & 78.8 & 443.2\end{array}$

203.9

469.5

443.2

23.71

St143

$\begin{array}{rrrrrr}30 & 575.1 & 272.0 & & 28.6 & 124.6 \\ 40 & 861.3 & 404.1 & & 303.4 & 237.8 \\ 50 & 612.4 & 664.3 & & 122.9 & 304.0 \\ 60 & 567.1 & 659.6 & 26.67 & 96.5 & 328.4\end{array}$

237.8

304.0

26.75

Lb3078

$\begin{array}{lllll}30 & 343.5 & 225.0 & 32.0 & 119.6\end{array}$

$\begin{array}{lllll}40 & 407.0 & 249.3 & 241.0 & 202.6\end{array}$

$\begin{array}{lllll}50 & 1672.5 & 550.4 & 133.9 & 294.9\end{array}$

$\begin{array}{lllllll}60 & 431.3 & 411.8 & 23.94 & 94.7 & 300.1 & 26.57\end{array}$

\begin{tabular}{lcccccc}
\hline $\mathrm{SEM}^{* *}$ & 37.39 & 15.31 & 0.78 & 11.45 & 8.42 & 0.74 \\
\hline $\mathrm{R}^{2^{* * *}}$ & 0.911 & 0.921 & 0.861 & 0.978 & 0.963 & 0.898 \\
\hline
\end{tabular}

${ }^{*} \mathrm{CCE}=\beta$-galactosidase-containing crude cellular extracts from Lb11842: Lb. delbrueckii ssp. bulgaricus 11842, St143: St. thermophilus 143, and Lb3078: Lb. delbrueckii ssp. lactis 3078; ${ }^{* *}$ SEM = adjusted standard error of the mean; ${ }^{* * *} \mathrm{R}^{2}=$ coefficient of the determination; $\mathrm{n}=12$ or more.

present in lactose and skim milk solutions after the termination of the lactose hydrolysis trials. These data were also used for the calculation of the degree of lactose conversion as described above. The highest degree of lactose conversion into total constitutive monosaccharides (58.7 and $62.5 \pm$ $0.65 \%$, respectively) was achieved by Lb11842 CCE in 5\% (w/w) lactose and $10 \%(\mathrm{w} / \mathrm{w})$ skim milk preparations. Lactose conversion into glucose was similar for the three tested strains at low lactose concentration $\left(50 \mathrm{mg} \cdot \mathrm{mL}^{-1}\right)$ in skim milk, but this conversion substantially increased for Lb11842 CCE in comparison with the other two CCEs with the increase of the lactose concentration (Tab. III). The lactose concentrations and temperatures affected the conversion of lactose to galactose significantly $(P<0.05)$, while the enzyme origin had no apparent effect. The glucose to galactose ratio differed from the theoretical value of $1: 1$ and generally ranged from 1.44 to $2.32 \pm 0.10$. The ratio obtained during lactose hydrolysis in skim milk was slightly but not significantly $(P>0.05)$ lower than in lactose preparations. Similar observations about the increased glucose/galactose ratio 
Table II. The content of monosaccharides as identified by HPLC analysis after termination of lactose hydrolysis in buffered lactose solutions conducted at different temperatures by $\beta$-galcontaining CCE preparations from three thermophilic dairy cultures.

\begin{tabular}{|c|c|c|c|c|c|c|c|c|}
\hline \multirow{3}{*}{$\begin{array}{l}\text { Lactose/ } \\
\text { CCE* }^{*}\end{array}$} & \multicolumn{8}{|c|}{ Monosaccharides $\left(\mathrm{mg} \cdot \mathrm{mL}^{-1}\right)$} \\
\hline & \multicolumn{4}{|c|}{ Glucose } & \multicolumn{4}{|c|}{ Galactose } \\
\hline & $30^{* * *}$ & 40 & 50 & 60 & 30 & 40 & 50 & 60 \\
\hline \multicolumn{9}{|c|}{$300^{* * * *}$} \\
\hline Lb11842 & 17.22 & 19.74 & 33.26 & 32.15 & 8 & 9.17 & 19.11 & 18.48 \\
\hline St143 & 15.05 & 15.96 & 24.58 & 20.33 & 7.12 & 7.54 & 14.11 & 10.81 \\
\hline Lb3078 & 12.59 & 14.73 & 22.35 & 20.08 & 7.33 & 6.68 & 11.25 & 13.08 \\
\hline \multicolumn{9}{|l|}{200} \\
\hline Lb11842 & 15.3 & 15.25 & 29.65 & 29.44 & 7.34 & 9.82 & 17.56 & 18.32 \\
\hline St143 & 9.99 & 14.09 & 25.61 & 21.72 & 4.37 & 6.48 & 11.05 & 13.82 \\
\hline Lb3078 & 8.78 & 12.7 & 17.92 & 17.86 & 5.45 & 5.65 & 10.94 & 12.61 \\
\hline \multicolumn{9}{|l|}{125} \\
\hline Lb11842 & 13.55 & 13.02 & 24.99 & 19.62 & 6.44 & 8.38 & 15.81 & 12.83 \\
\hline St143 & 10.99 & 13.09 & 23.33 & 15.5 & 6.4 & 6.18 & 11.56 & 10.95 \\
\hline Lb3078 & 10.13 & 15.32 & 14.59 & 12.8 & 5.54 & 2.63 & 9.77 & 8.54 \\
\hline \multicolumn{9}{|l|}{50} \\
\hline Lb11842 & 10.74 & 11.1 & 18.27 & 18.24 & 5.26 & 5.67 & 9.87 & 11.33 \\
\hline St143 & 7.5 & 8.2 & 11.99 & 10.56 & 3.52 & 3.98 & 6.17 & 7.32 \\
\hline Lb3078 & 7.05 & 7.48 & 8.77 & 9.13 & 3.78 & 4.05 & 4.26 & 5.48 \\
\hline $\mathrm{SEM}^{+}$ & \multicolumn{4}{|c|}{0.53} & \multicolumn{4}{|c|}{0.38} \\
\hline
\end{tabular}

${ }^{*} \mathrm{CCE}=\beta$-galactosidase-containing crude cellular extracts from Lb11842: Lb. delbrueckii ssp. bulgaricus 11842, St143: St. thermophilus 143, and Lb3078: Lb. delbrueckii ssp. lactis $3078 ;{ }^{* *}$ temperature in ${ }^{\circ} \mathrm{C} ;{ }^{* * *}$ lactose concentration in $\mathrm{mg} \cdot \mathrm{mL}^{-1} ;{ }^{+} \mathrm{SEM}=$ adjusted standard error of the mean; $\mathrm{n}=4$ or more.

during the early stages of lactose hydrolysis observed by others [11,27] were attributed to the formation of the transferase products containing mainly galactose.

\subsection{Transferase reactions by $\mathrm{CCE}$ preparations}

Lactose hydrolysis by all $\beta$-gal-containing CCEs in all reaction mixtures resulted in the formation of other carbohydrates in addition to the major hydrolysis products glucose and galactose. Typical chromatograms from the HPLC analysis of the lactose-hydrolyzed samples obtained using the Lb11842 CCE are shown in Figure 1; the use of the other two CCEs resulted in similar chromatograms (data not shown). The chromatogram " $A$ ", acquired using the
Jordi oligosaccharide column, shows separation of all carbohydrates into size classes; however, separation within the classes was not achieved. A better separation for monoand disaccharides was obtained using the Supelcosil column (chromatogram "B"), but the peak for tetrasaccharides did not appear and trisaccharides (peak 3 ) were partitioned poorly. The formation of tetrasaccharides in skim milk at all concentrations and temperatures was revealed only for Lb3078 CCE (Tab. V). The reason for this observation remained unclear; either oligosaccharides formed by Lb11842 or St143 CCE were below a detectable limit or different kinetic parameters at low lactose concentrations were responsible for a kinetic shift towards the formation of monosaccharides [11]. The peaks $2 \mathrm{~b}$ and $2 \mathrm{c}$ appeared in all 


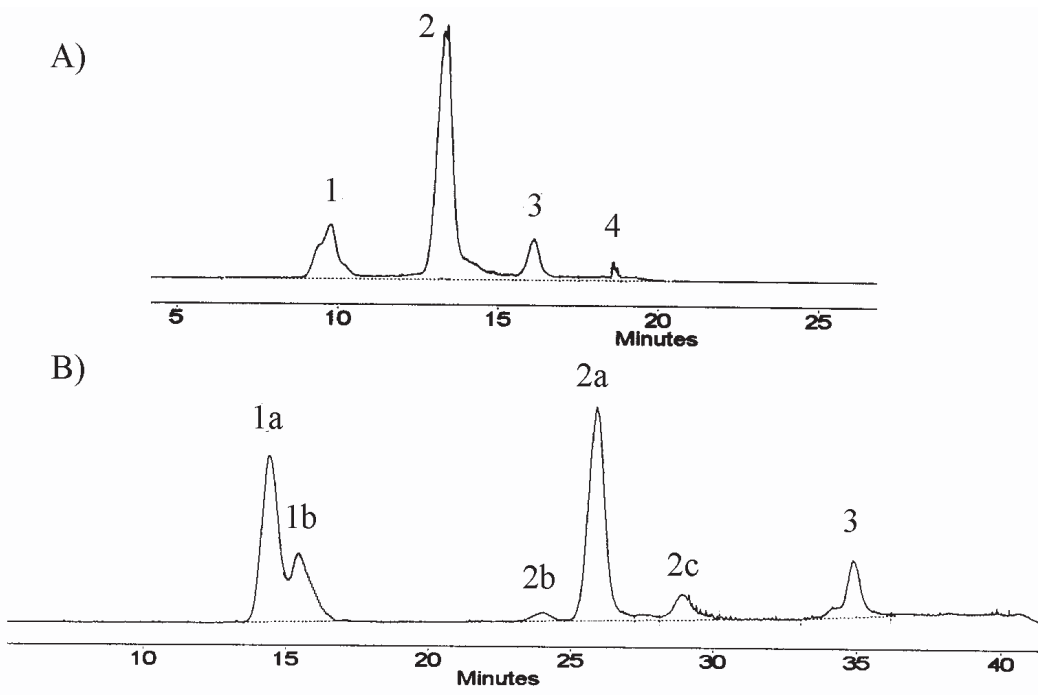

Figure 1. Typical HPLC chromatograms obtained when analyzing products of the lactose hydrolysis by the Lb11842 CCE preparation as acquired by (A) Jordi oligosaccharide or (B) Supelcosil carbohydrate columns (peaks identified as follows: $1=$ monosaccharides; $2=$ disaccharides; $3=$ trisaccharides; $4=$ tetrasaccharides $; 1 \mathrm{a}=$ glucose $; 1 \mathrm{~b}=$ galactose $; 2 \mathrm{a}=$ lactose $; 2 \mathrm{~b}$ and $2 \mathrm{c}=$ unidentified disaccharides).

Table III. The content of monosaccharides as identified by HPLC analysis after termination of lactose hydrolysis in skim milk preparations conducted at different temperatures by $\beta$-gal-containing CCE preparations from three thermophilic dairy cultures.

\begin{tabular}{|c|c|c|c|c|c|c|c|c|}
\hline \multirow{3}{*}{$\begin{array}{l}\text { Lactose/ } \\
\text { CCE }^{*}\end{array}$} & \multicolumn{8}{|c|}{ Monosaccharides $\left(\mathrm{mg} \cdot \mathrm{mL}^{-1}\right)$} \\
\hline & \multicolumn{4}{|c|}{ Glucose } & \multicolumn{4}{|c|}{ Galactose } \\
\hline & $30^{\text {*** }}$ & 40 & 50 & 60 & 30 & 40 & 50 & 60 \\
\hline \multicolumn{9}{|c|}{$150^{* * *}$} \\
\hline Lb11842 & 13.87 & 18.6 & 27.76 & 29.83 & 7.24 & 9.61 & 17.09 & 16.09 \\
\hline St143 & 7.86 & 12.23 & 14.27 & 23.35 & 3.69 & 6.29 & 6.65 & 11.76 \\
\hline Lb3078 & 7.41 & 11.27 & 13.5 & 14.54 & 3.64 & 5.37 & 7.21 & 8.2 \\
\hline \multicolumn{9}{|l|}{100} \\
\hline Lb11842 & 12.3 & 14.01 & 24.39 & 22.35 & 6.89 & 8.17 & 14.07 & 13.19 \\
\hline St143 & 7.23 & 10.56 & 20.17 & 19.88 & 3.82 & 5.72 & 10.31 & 10.33 \\
\hline Lb3078 & 6.97 & 10.39 & 18.33 & 15.78 & 3.75 & 5.48 & 10.89 & 9.58 \\
\hline \multicolumn{9}{|c|}{50} \\
\hline Lb11842 & 14.77 & 11.47 & 19.5 & 18.7 & 8.98 & 7.01 & 11.58 & 11.3 \\
\hline St143 & 13.83 & 8.33 & 15.83 & 16.8 & 7.85 & 4.8 & 8.4 & 9.97 \\
\hline Lb3078 & 11.85 & 7.89 & 13.48 & 14.97 & 6.82 & 4.68 & 8.62 & 9.51 \\
\hline SEM $^{+}$ & \multicolumn{4}{|c|}{0.26} & \multicolumn{4}{|c|}{0.34} \\
\hline
\end{tabular}

${ }^{*} \mathrm{CCE}=\beta$-galactosidase-containing crude cellular extracts from Lb11842: Lb. delbrueckii ssp. bulgaricus 11842, St143: St. thermophilus 143, and Lb3078: Lb. delbrueckii ssp. lactis 3078; ${ }^{* *}$ temperature in ${ }^{\circ} \mathrm{C}$; ${ }^{* * *}$ lactose concentration in $\mathrm{mg} \cdot \mathrm{mL}^{-1} ;{ }^{+} \mathrm{SEM}=$ adjusted standard error of the mean; $\mathrm{n}=4$ or more. 
Table IV. The content of oligosaccharides formed during lactose hydrolysis in buffered lactose solutions as identified by HPLC analysis after termination of lactose hydrolysis reactions conducted at different temperatures by $\beta$-gal-containing CCE preparations from three thermophilic dairy cultures.

\begin{tabular}{|c|c|c|c|c|c|c|c|c|c|c|c|c|}
\hline \multicolumn{13}{|c|}{ Sugars $\left(\mathrm{mg} \cdot \mathrm{mL}^{-1}\right)$} \\
\hline \multirow{2}{*}{$\begin{array}{c}\text { Lactose/ } \\
\text { CCE }^{*}\end{array}$} & \multicolumn{4}{|c|}{ Total disaccharides ${ }^{* *}$} & \multicolumn{4}{|c|}{ Trisaccharides } & \multicolumn{4}{|c|}{ Tetrasaccharides } \\
\hline & $30^{* * * *}$ & 40 & 50 & 60 & 30 & 40 & 50 & 60 & 30 & 40 & 50 & 60 \\
\hline \multicolumn{13}{|l|}{$300^{+}$} \\
\hline Lb11842 & 13.07 & 19.42 & 22.98 & 14.67 & 8.14 & 16.29 & 26.83 & 16.94 & 1.22 & 1.31 & 1.52 & 1.7 \\
\hline St143 & 13.37 & 20.05 & 25.36 & 20.52 & 9.21 & 18.46 & 32.77 & 25.45 & 1.32 & 1.36 & 1.95 & 1.79 \\
\hline Lb3078 & 9.61 & 13.15 & 15.91 & 13.55 & 6.04 & 9.61 & 20.42 & 12.34 & 0.73 & 0.73 & 0.91 & 1.16 \\
\hline \multicolumn{13}{|c|}{ 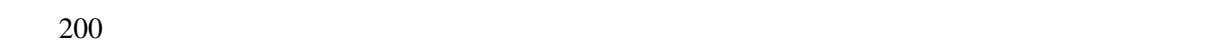 } \\
\hline Lb11842 & 8.17 & 9.66 & 14.66 & 13.47 & 6.92 & 11.11 & 16.75 & 8.7 & 1.03 & 1.02 & 0.91 & 1.14 \\
\hline St143 & 9.59 & 12.70 & 15.96 & 14.72 & 7.59 & 11.96 & 15.83 & 12.44 & 1.32 & 1.06 & 0.96 & 1.16 \\
\hline Lb3078 & 7.38 & 8.59 & 12.26 & 12.90 & 2.65 & 7.88 & 7.59 & 6.66 & 0.67 & 0.67 & 0.79 & 0.92 \\
\hline \multicolumn{13}{|l|}{125} \\
\hline Lb11842 & 6.35 & 6.91 & 8.82 & 8.71 & 6.91 & 6.17 & 10.03 & 9.74 & 1.44 & 1.04 & 1.15 & 0.87 \\
\hline St143 & 7.09 & 7.16 & 10.08 & 9.75 & 3.79 & 7.19 & 9.13 & 6.28 & 1.52 & 1.04 & 1.26 & 0.87 \\
\hline Lb3078 & 4.95 & 5.03 & 7.93 & 7.73 & 2.3 & 5.75 & 5.96 & 3.48 & 0.57 & 0.57 & 0.61 & 0.77 \\
\hline \multicolumn{13}{|l|}{50} \\
\hline Lb11842 & 3.13 & 3.29 & 3.59 & 3.52 & 1.7 & 2.27 & 3.76 & 3.41 & 0.47 & 1.11 & 1.02 & 0.9 \\
\hline St143 & 3.33 & 4.21 & 4.79 & 4.08 & 1.47 & 2.46 & 3.05 & 2.7 & 0.6 & 1.19 & 1.27 & 0.86 \\
\hline Lb3078 & 2.97 & 2.72 & 3.98 & 3.21 & 1.59 & 1.75 & 2.33 & 2.29 & 0.37 & 0.37 & 0.54 & 0.68 \\
\hline $\mathrm{SEM}^{++}$ & \multicolumn{4}{|c|}{0.16} & \multicolumn{4}{|c|}{0.11} & \multicolumn{4}{|c|}{0.13} \\
\hline
\end{tabular}

${ }^{*} \mathrm{CCE}=\beta$-galactosidase-containing crude cellular extracts from Lb11842: Lb. delbrueckii ssp. bulgaricus 11842, St143: St. thermophilus 143, and Lb3078: Lb. delbrueckii ssp. lactis 3078; ${ }^{* *}$ other than lactose; ${ }^{* * *}$ temperature in ${ }^{\circ} \mathrm{C} ;{ }^{+}$lactose concentration in $\mathrm{mg} \cdot \mathrm{mL}^{-1} ;{ }^{++} \mathrm{SEM}=$ adjusted standard error of the mean; $\mathrm{n}=4$ or more.

processed systems, with combined maxima up to $9.5 \pm 0.16 \%$ of the total sugars, and could likely represent disaccharides other than lactose. Huber et al. [11] and Greenberg and Mahoney [10] reported formation of allolactose (6- $O$-galactosyl- $\beta$-D-glucopyranose) and 6- $O$-galactosyl- $\beta$-D-galactopyranose as major products of the transferase reactions during lactose hydrolysis. The formation of pentasaccharides or hexasaccharides was not detected in any of the processed systems, although their formation by $S t$. thermophilus $\beta$-gal was reported [30]. Also, our results were in contrast to the report of Greenberg and Mahoney [10], who detected only disaccharides and no higher oligosaccharides in the St. thermophilus $\beta$-gal lactose-hydrolyzed skim milk, possibly due to the different detec- tion methodologies used. Figures $2 \mathrm{~A}$ and 2B show the rate of the oligosaccharide production by the three tested CCEs, indicating that the St143 CCE had a greater oligosaccharide producing ability than the other two CCEs. Consequently, the HPLCgenerated-chromatograms resulted in different peak heights, but the HPLC-patterns of the transferase product formation by all three examined CCE preparations were similar, indicating at least the size similarity of the formed oligosaccharides.

The formation of oligosaccharides was significantly $(P<0.001)$ affected by all examined variables (enzyme origin, lactose concentration, temperature and time). The highest oligosaccharide production was achieved at $50{ }^{\circ} \mathrm{C}$ in $30 \%(\mathrm{w} / \mathrm{w})$ lactose solution for all CCEs examined. The St143 
Table V. The content of oligosaccharides formed during lactose hydrolysis in skim milk preparations as identified by HPLC analysis after termination of lactose hydrolysis reactions conducted at different temperatures by $\beta$-gal-containing CCE preparations from three thermophilic dairy cultures.

\begin{tabular}{|c|c|c|c|c|c|c|c|c|c|c|c|c|}
\hline \multirow{3}{*}{$\begin{array}{c}\text { Lactose/ } \\
\mathrm{CCE}^{*}\end{array}$} & \multicolumn{12}{|c|}{ Sugars $\left(\mathrm{mg} \cdot \mathrm{mL}^{-1}\right)$} \\
\hline & \multicolumn{4}{|c|}{ Total disaccharides** } & \multicolumn{4}{|c|}{ Trisaccharides } & \multicolumn{4}{|c|}{ Tetrasaccharides } \\
\hline & $30^{* * * *}$ & 40 & 50 & 60 & 30 & 40 & 50 & 60 & 30 & 40 & 50 & 60 \\
\hline \multicolumn{13}{|l|}{$150^{+}$} \\
\hline Lb11842 & 6.67 & 8.80 & 10.34 & 10.09 & 7.26 & 9.08 & 8.4 & 6.6 & \multicolumn{4}{|c|}{$\mathrm{ND}^{++}$} \\
\hline St143 & 7.15 & 9.10 & 12.28 & 10.40 & 8 & 8.98 & 12.58 & 9.89 & \multicolumn{4}{|c|}{ ND } \\
\hline Lb3078 & 6.59 & 8.52 & 6.25 & 6.45 & 3.86 & 6.6 & 7.58 & 8 & 0.61 & 0.63 & 0.73 & 0.82 \\
\hline \multicolumn{13}{|l|}{100} \\
\hline Lb11842 & 3.92 & 5.59 & 7.11 & 5.90 & 4.51 & 5.27 & 5.07 & 4.82 & \multicolumn{4}{|c|}{ ND } \\
\hline St143 & 4.21 & 6.73 & 7.27 & 6.90 & 3.74 & 4.15 & 5.06 & 4.81 & \multicolumn{4}{|c|}{ ND } \\
\hline Lb3078 & 3.77 & 5.37 & 5.47 & 2.90 & 4.29 & 4.29 & 4.69 & 4.81 & 0.52 & 0.53 & 0.68 & 0.74 \\
\hline \multicolumn{13}{|l|}{50} \\
\hline Lb11842 & 2.17 & 3.61 & 3.88 & 3.06 & 1.14 & 1.09 & 1.15 & 1.38 & \multicolumn{4}{|c|}{ ND } \\
\hline St143 & 3.39 & 4.01 & 3.99 & 3.24 & 2.2 & 2.46 & 2.49 & 2.38 & \multicolumn{4}{|c|}{ ND } \\
\hline Lb3078 & 2.17 & 3.41 & 3.28 & 2.47 & 1.93 & 2.11 & 2.2 & 2.38 & 0.34 & 0.35 & 0.5 & 0.65 \\
\hline SEM $^{+++}$ & \multicolumn{4}{|c|}{0.34} & \multicolumn{4}{|c|}{0.21} & \multicolumn{4}{|c|}{0.05} \\
\hline
\end{tabular}

${ }^{*} \mathrm{CCE}=\beta$-galactosidase-containing crude cellular extracts from Lb11842: Lb. delbrueckii ssp. bulgaricus 11842, St143: St. thermophilus 143, and Lb3078: Lb. delbrueckii ssp. lactis 3078; ${ }^{* *}$ other than lactose; ${ }^{* *}$ temperature in ${ }^{\circ} \mathrm{C} ;{ }^{+}$lactose concentration in $\mathrm{mg} \cdot \mathrm{mL}^{-1} ;{ }^{++} \mathrm{ND}=$ not detected; ${ }^{+++} \mathrm{SEM}=$ adjusted standard error of the mean; $n=4$ or more.

CCE was a significantly better $(P<0.05)$ total oligosaccharides producer - including newly formed disaccharides - than the other two CCEs originating from Lactobacillus sp. at all lactose concentrations and temperatures studied. The maximum oligosaccharide concentration, approx. $20 \%$ of the total carbohydrates $\left(60.1 \mathrm{mg} \cdot \mathrm{mL}^{-1}\right)$ produced by St143 CCE, was reached in $30 \%(\mathrm{w} / \mathrm{w})$ lactose preparation at $50^{\circ} \mathrm{C}$ after $120 \mathrm{~min}$, in comparison with Lb11842 or Lb3078 CCE (51.3 or $37.2 \mathrm{mg} \cdot \mathrm{mL}^{-1}$, respectively), under the same conditions (Tab. IV). Toba et al. [31] and later Garman et al. [6] also reported the high transferase activity of the St. thermophilus $\beta$-gal.

The effect of the lactose concentration has been recognized previously [11, 13, 23] with the temperature effect appearing to be species-dependent [22]. In the present study, all three CCE preparations followed a similar pattern, achieving the oligosaccharide production maxima at the same temperature
(Tabs. IV and V). The maximum oligosaccharide production (approx 20\% and 16.5\% of the total sugars in lactose and skim milk systems, respectively) achieved by St143 CCE in our study was lower than the values reported previously for St. thermophilus $\beta$-gal - up to $25 \%$ in milk [10] or $40 \%$ in a buffered lactose solution [25] - but comparable with those for $E$. coli and $K$. lactis $\beta$-gal in lactose solutions and skim milk [19]. Noticeably, oligosaccharide production was lower in skim milk than in lactose preparations even at the same $\left(50 \mathrm{mg} \cdot \mathrm{mL}^{-1}\right)$ lactose concentration (Figs. 2A and 2B; Tabs. IV and V). Although lower in the total amount, the maximum of the oligosaccharide production by the $\beta$-gal-containing CCEs was reached sooner (after $60 \mathrm{~min})$ at low $\left(50 \mathrm{mg} \cdot \mathrm{mL}^{-1}\right)$ rather than high $\left(300 \mathrm{mg} \cdot \mathrm{mL}^{-1}\right)$ lactose concentrations and remained fairly constant until termination (Fig. 2A). Indicatively, the maximum of the oligosaccharide production was not reached for Lb11842 and 

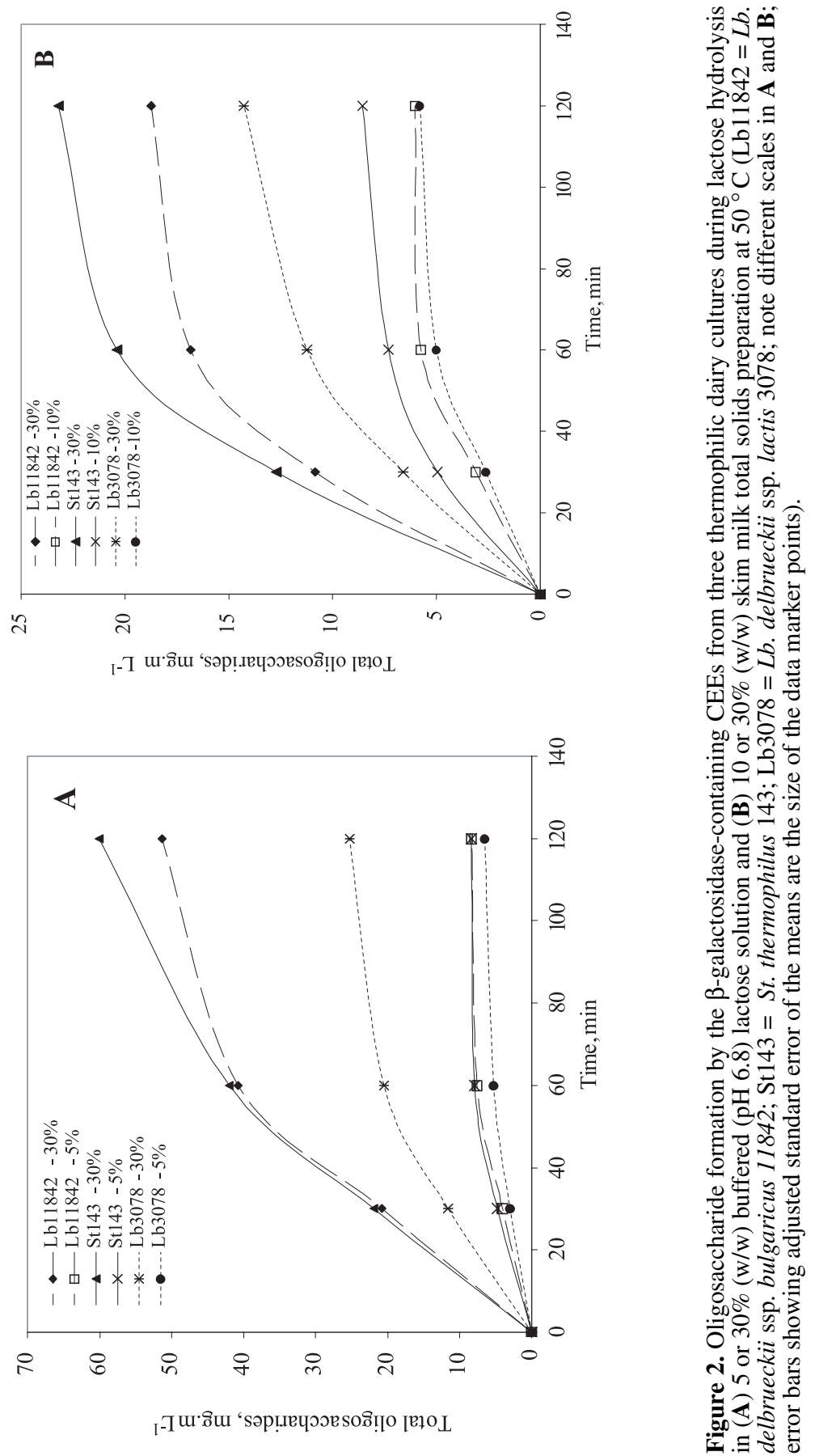

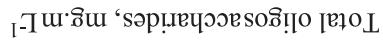




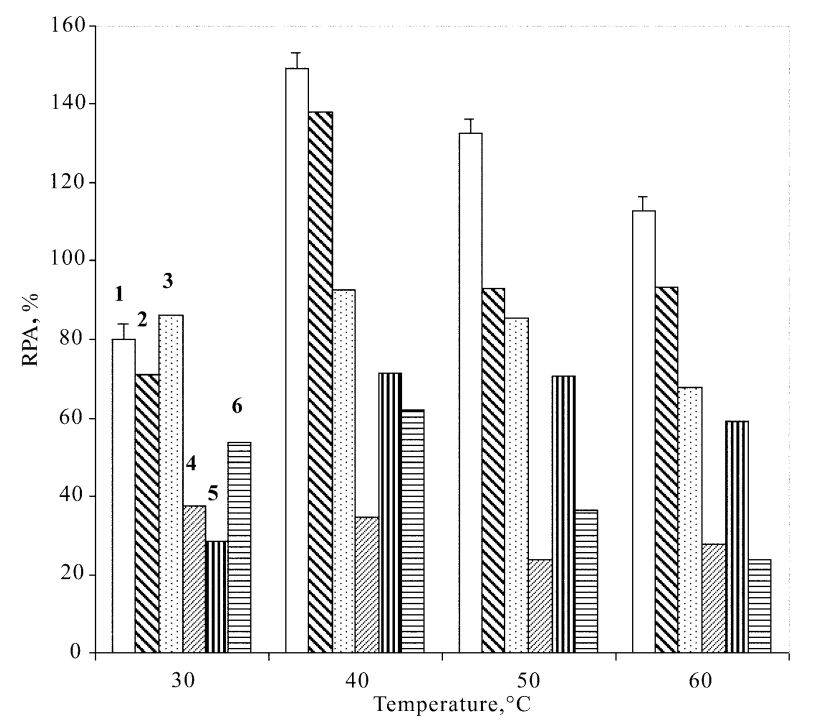

Figure 3. Relative proteolytic activity (RPA, \%) of the $\beta$-galcontaining CEEs from three thermophilic dairy cultures during lactose hydrolysis in 10 or $30 \%(\mathrm{w} / \mathrm{w})$ skim milk preparation performed at different temperatures (numbers on top of bars indicate CCE containing reaction systems as follows: 1 = Lb11842: Lb. delbrueckii ssp. bulgaricus $11842-$ 10\%; $2=$ Lb11842: $30 \% ; 3=$ St143: St. thermophilus 143 $10 \% ; 4=$ St143 - 30\%; $5=$ Lb3078: Lb. delbrueckii ssp. lactis 3078 - 10\%; 6 = Lb3078 $-30 \%$; same order used for all temperature sets; bars present adjusted standard error of the means; $n=4$ or more).
St143 CCE, likely due to insufficient lactose hydrolysis. Prenosil et al. [22] correlated the oligosaccharide production with a high degree of lactose hydrolysis, achieving maxima when up to $80 \%$ of lactose was hydrolyzed. Based on their findings, a higher amount of oligosaccharides might have been produced in our study by prolonging the lactose hydrolysis reaction time.

\subsection{Total proteolytic activity of CCE preparations}

All three $\beta$-gal-containing CCE preparations exhibited appreciable proteolytic activity in skim milk systems. The proteolytic activity of the CCE preparations resulted in a steady increase in the total surface area under the HPLC peptide peaks over the time of the hydrolysis, reaching maxima at the 120 min reaction time endpoint. Figure 3 shows the maxima obtained for the proteolytic activities of the three CCEs in 10 or $30 \%$ skim milk reaction systems, after the termination of the hydrolysis. Generally, the values obtained for the $20 \%$ skim milk preparations were between the respective data pairs presented in Figure 3 (data not shown). Although covariate adjustment using the cell paste total solids was significant $(P=0.0329)$, the adjusted proteolytic activity still differed significantly $(P<0.05)$ between the CCE sources, with Lb11842 CCE being the most proteolytic. Such a high capability of the CCE preparations to hydrolyze milk proteins is obviously related to the absence of the purification step during the CCE production $[32,33]$. On the other hand, the substantial activity differences follow from the origin of the CCE preparations. Shihata and Shah [26], comparing proteolytic activity of several LAB species, showed that $L b$. bulgaricus and St. thermophilus strains were highly proteolytic in comparison with $L b$. acidophilus and Bifidobacterium sp. strains.

The concentration of the skim milk total solids had a significant $(P<0.05)$ effect on the amount of peptides formed through the proteolysis, higher concentrations resulting in lower proteolytic activity (Fig. 3). Such an effect of the increased skim milk total solids might have resulted from the concomitant decrease in water activity, which could have had an inhibitory effect on the proteolytic activity of the studied CCE preparations [9]. The proteolytic activity 
of all CCE preparations clearly showed temperature dependence, reaching maxima for all three CCE preparations at $40{ }^{\circ} \mathrm{C}$, in concert with previously reported findings [33]. Similarly, Abraham et al. [1] and Fira et al. [4] reported enhanced proteolytic activity of Lb. bulgaricus around $40^{\circ} \mathrm{C}$ as opposed to $L b$. acidophilus strains with maximum at $50{ }^{\circ} \mathrm{C}$ [1]. The differences in temperature optima between the proteolysis and transferase reactions for all three CCEs used in our study give a possible tool for manipulating these activities depending on the desired end-use of the CCE.

\section{CONCLUSIONS}

All the $\beta$-gal-containing CCE preparations obtained from three thermophilic dairy cultures studied were able to catalyze the formation of oligosaccharides. The formation rate and the amount of oligosaccharides were origin-specific while the effects of lactose concentration and temperature were substantial in all cases. The highest oligosaccharide production was achieved by St 143 at $30 \%$ lactose concentration, followed by Lb11842 and Lb3078 CCEs. The maximum oligosaccharide production (approximately $20 \%$ of the total sugars) was reached at $50{ }^{\circ} \mathrm{C}$ with $30 \%$ (w/w) lactose concentration using the St143 CCE. The amount of the oligosaccharides formed by all $\mathrm{CCE}$ preparations was substantially lower in skim milk in comparison with corresponding lactose solutions; no tetrasaccharides were detected in skim milk preparations when using Lb11842 or St3078 CCE. The lactose hydrolysis by all CCE preparations resulted in the formation of at least two different disaccharides, likely allolactose and 6- $O$-galactosyl$\beta$-D-galactopyranose. The rate of production of the constitutive monosaccharides achieved by Lb1 1842 CCE was faster than for the other two enzyme preparations, subsequently resulting in higher $\mathrm{k}_{\mathrm{cat}}$ values at corresponding temperatures. Similarly, Lb11842 CCE exhibited higher proteolytic activity than the other two studied CCEs. The maximum proteo- lytic activity was generally reached at $40{ }^{\circ} \mathrm{C}$ in $10 \%$ skim milk and decreased at higher concentrations of skim milk total solids ( 20 or $30 \% \mathrm{w} / \mathrm{w}$ ). The characterization and simultaneous optimization of the lactose hydrolysis, oligosaccharide formation and proteolytic activity of different CCEs in various lactose-containing preparations may be important for some industrial applications, such as using the CCE preparations as a fermentation enhancer.

Acknowledgements: Funding for this project was provided in part by the NSERC Research Network on Lactic Acid Bacteria, administered by the Université Laval and including Novalait Inc., Dairy Farmers of Canada, Institute Roselle Inc., and Agriculture and Agrifood Canada.

\section{REFERENCES}

[1] Abraham A.G., De Antoni G.L., Anon M.C., Proteolytic activity of Lactobacillus bulgaricus grown in milk, J. Dairy Sci. 76 (1993) 1498-1505.

[2] Boels I.C., Ramos A., Kleerebezem M., De Vos W.M., Functional analysis of the Lactococcus lactis galU and galE genes and their impact on sugar nucleotide and exopolysaccharide biosynthesis, Appl. Microbiol. Biotechnol. 67 (2001) 3033-3040.

[3] Bouhnik Y., Flourie B., D’Agay-Abensour L., Pochart P., Gramet G., Durand M., Rambaud J.C., Administration of transgalacto-oligosaccharides increases fecal bifidobacteria and modifies colonic fermentation metabolism in healthy humans, J. Nutr. 27 (1997) 444-448.

[4] Fira D., Kojic M., Banina A., Spasojevic I., Strahinic I., Topisirovic L., Characterization of cell envelope-associated proteinases of thermophilic lactobacilli, J. Appl. Microbiol. 90 (2001) 123-130.

[5] Gallaher D.D., Khil J., The effect of synbiotics on colon carcinogenesis in rats, J. Nutr. 129 (1999) 1483S-1487S.

[6] Garman J., Coolbear T., Smart J., The effect of cations on the hydrolysis of lactose and the transferase reactions catalyzed by $\beta$ galactosidase from six strains of lactic acid bacteria, Appl. Microbiol. Biotechnol. 46 (1996) 22-27.

[7] Geciova J., Comparison of $\beta$-galactosidase production by dairy cultures in whey media with whey protein concentrate adjuncts, 
Graduation diploma thesis, VSCHT, Prague, Czech Republic, 1999, pp. 43-51.

[8] Geciova J., Giesova M., Jelen P., Plockova M., Disruption of Streptococcus thermophilus 143 culture by three mechanical methods for increased $\beta$-galactosidase activity, Milchwissenschaft 57 (2002) 509-511.

[9] Gobbetti M., Lanciotti R., De Angelis M., Corbo M.R., Massini R., Fox P., Study of the effects of temperature, $\mathrm{pH}, \mathrm{NaCl}$, and $\mathrm{a}(\mathrm{w})$ on the proteolytic and lipolytic activities of cheese-related lactic acid bacteria by quadratic response surface methodology, Enzyme Microb. Technol. 25 (1999) 795-809.

[10] Greenberg N.A., Mahoney R.R., Formation of oligosaccharides by $\beta$-galactosidase from Streptococcus thermophilus, Food Chem. 10 (1983) 195-204.

[11] Huber R.E., Kurz G., Wallenfels K., A quantitation of the factors which affect the hydrolase and transgalactosylase activities of $\beta$-galactosidase (E. coli) on lactose, Biochemistry 15 (1976) 1994-2001.

[12] Itoh T., Ohhashi M., Toba T., Adachi S., Purification and properties of $\beta$-galactosidase from Lactobacillus bulgaricus, Milchwissenschaft 35 (1980) 593-597.

[13] Iwasaki K., Nakajima M., Nakao S., Galactooligosaccharide production from lactose by an enzymic batch reaction using $\beta$-galactosidase, Process Biochem. 33 (1996) 69-76.

[14] Jelen P., Lactose hydrolysis using sonicated dairy cultures, Bull. Int. Dairy Fed. 289 (1993) 54-56.

[15] Kreft M., Jelen P., Stability and activity of $\beta$ galactosidase in sonicated cultures of Lactobacillus delbrueckii subsp. bulgaricus 11842 as affected by temperature and ionic environments, J. Food Sci. 65 (2000) 1364-1368.

[16] Kreft M., Roth L., Jelen P., Lactose hydrolyzing ability of sonicated cultures of Lactobacillus delbrueckii subsp. bulgaricus 11842, Lait 81 (2001) 355-364.

[17] Kunji E.R.S., Mierau I., Hagting A., Poolman B., Konings W.N., The proteolytic systems of lactic acid bacteria, Antonie van Leeuwenhoek 70 (1996) 187-221.

[18] Mahoney R.R., Galactosyl-oligosaccharide formation during lactose hydrolysis: a review, Food Chem. 63 (1998) 147-154.

[19] Modler H.W., Gelda A., Yaguchi M., Gelda S., Production of fluid milk with a high degree of lactose hydrolysis, Bull. Int. Dairy Fed. 289 (1993) 57-61.

[20] Mozaffar Z., Nakanishi K., Matsuno R., Formation of oligosaccharides during hydrolysis of lactose in milk using $\beta$-galactosidase from Bacillus circulans, J. Food Sci. 50 (1985) 1602-1606.
[21] Prenosil J.E., Stuker E., Bourne J.R., Formation of oligosaccharides during enzymatic lactose hydrolysis and their importance in a whey hydrolysis process. Part I: state of art, Biotechnol. Bioeng. 30 (1987) 1019-1025.

[22] Prenosil J.E., Stuker E., Bourne J.R., Formation of oligosaccharides during enzymatic lactose hydrolysis and their importance in a whey hydrolysis process. Part II: experimental, Biotechnol. Bioeng. 30 (1987) 1026-1031.

[23] Reuter S., Nygaard A.R., Zimmermann W., $\beta$ galactooligosaccharide synthesis with $\beta$-galactosidases from Sulfolobus solfataricus, Aspergillus oryzae, and Escherichia coli, Enzyme Microb. Technol. 25 (1999) 509-516.

[24] Santos A., Ladero M., Garcia-Ochoa F., Kinetic modeling of lactose hydrolysis by a $\beta$-galactosidase from Kluyveromyces fragilis, Enzyme Microb. Technol. 22 (1998) 558-567.

[25] Shah N.P., Jelen P.J., Lactase activity and properties of sonicated dairy cultures, Milchwissenschaft 46 (1991) 570-573.

[26] Shihata A., Shah N.P., Proteolytic profiles of yogurt and probiotic bacteria, Int. Dairy J. 10 (2000) 401-408.

[27] Smart J., Transferase reactions of the $\beta$-galactosidase from Streptococcus thermophilus, Appl. Microbiol. Biotechnol. 34 (1991) 495-501.

[28] Tsakalidou E., Anastasiou R., Vandenberghe I., Van Eeumen J., Kalantzopoulos G., Cellwall-bound proteinase of Lactobacillus delbrueckii subsp. lactis ACA-DC 178: characterization and specificity for $\beta$-casein, Appl. Environ. Microbiol. 65 (1999) 2035-2040.

[29] Toba T., Adachi S., Hydrolysis of lactose by microbial $\beta$-galactosidases. Formation of oligosaccharides with special reference to $2-O$ $\beta$-D-galactopyranosyl-D-glucose, J. Dairy Sci. 61 (1978) 33-38.

[30] Toba T., Tomita Y., Itoh T., Adachi S., $\beta$ galactosidases of lactic acid bacteria: characterization by oligosaccharides formed during hydrolysis of lactose, J. Dairy Sci. 64 (1981) 185-192.

[31] Toba T., Yokota A., Adachi S., Oligosaccharide structures formed during the hydrolysis of lactose by Aspergillus oryzae $\beta$-galactosidase, Food Chem. 16 (1985) 147-162.

[32] Vasiljevic T., Jelen P., Production of $\beta$ galactosidase for lactose hydrolysis in milk and dairy products using thermophilic lactic acid bacteria, Innov. Food Sci. Emerg. Technol. 2 (2001) 75-85.

[33] Vasiljevic T., Jelen P, Lactose hydrolysis in milk as affected by neutralizers used for preparation of crude $\beta$-galactosidase extracts from Lactobacillus bulgaricus 11842, Innov. Food Sci. Emerg. Technol. 3 (2002) 175-184. 
[34] Vasiljevic T., Jelen P., Retention of $\beta$-galactosidase activity in crude cellular extracts from Lactobacillus delbrueckii ssp. bulgaricus 11842 upon drying, Int. J. Dairy Technol. 56 (2003) 111-116.

[35] Vasiljevic T., Jelen P., Drying and storage of crude $\beta$-galactosidase extracts from Lactoba- cillus delbrueckii ssp. bulgaricus 11842, Innov. Food Sci. Emerg. Technol. (2003) (in press).

[36] Whitaker J.R., Effect of substrate concentration on rates of enzyme-catalyzed reactions, in: Principles of enzymology for the food sciences, Marcel Dekker Inc., New York, USA, 1994, pp. 167-199. 